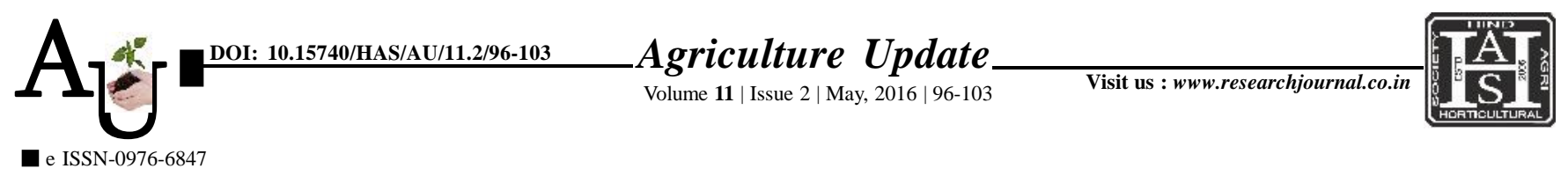

\title{
Rвеваксн автісі: : An analysis of technical and allocative efficiency of brinjal farm in Bilaspur district of Chhattisgarh
}

\author{
Article Chronicle: \\ Received : \\ 04.01.2016; \\ Revised : \\ 05.03.2016; \\ Accepted : \\ 07.04.2016
}

\section{KeY WoRds:}

Technical efficiency, Allocative efficiency, Stochastic frontier production, Maximum likelihood estimates, Return to scale
Author for correspondence:

\author{
AJAY TEGAR \\ Department of \\ Agricultural Economics, \\ T.C.B. College of \\ Agriculture and Research \\ Station, Sarkanda \\ BILASPUR \\ (C.G.) INDIA \\ Email: tegar17575@ \\ gmail.com
}

See end of the article for

authors' affiliations
SUMMARY : The study investigated the technical efficiency and allocative efficiency of brinjal farm in Bilaspir district of Chhattisgarh, using a stochastic frontier production function. Pre-tested questionnaires were used to collect the primary data from 154 randomly selected respondents. The study revealed return to scale on brinjal farm positive and less than unity as 0.58 which indicated that brinjal production in stage two of the production surface. The stochastic frontier analysis showed that 22.3 per cent of the variation in brinjal output attributed to technical efficiencies differences among the production units. About 77.7 per cent of the variation in output was due to random factors such as unfavourable weather, water scarcity, pest and disease attack and other factors outside the control of producer including errors in data collection and aggregation. The mean technical efficiency of the pooled sample accounted to be 96.1 per cent. Allocative efficiency in production of brinjal was not optimum as input variables were either under utilized or over utilized. Allocative efficiency of labour in brinjal production seed was under utilized. Rests of the input variables were over utilized. No farm from different categories size groups of farms of vegetable growers found using the resources efficiently.

How to cite this article : Tegar, Ajay, Banafar, K.N.S., Gauraha, A.K. and Chandrakar, G. (2016). An analysis of technical and allocative efficiency of brinjal farm in Bilaspur district of Chhattisgarh. Agric. Update, 11(2): 96103 (DOI : 10.15740/HAS/AU/11.2/96-103). 